\title{
“DWINDLING DOWN TO FARCE"?: APHRA BEHN'S APPROACH TO FARCE IN THE LATE 1670S AND 80S
}

\author{
Jorge Figueroa Dorrego ${ }^{1}$ \\ Universidade de Vigo \\ jdorrego@uvigo.es
}

\begin{abstract}
In spite of her criticism against farce in the paratexts of The Emperor of the Moon (1687), Aphra Behn makes an extensive use of farcical elements not only in that play and The False Count (1681), which are actually described as farces in their title pages, but also in Sir Patient Fancy (1678), The Feign'd Curtizans (1679), and The Second Part of The Rover (1681). This article contends that Behn adapts French farce and Italian commedia dell'arte to the English Restoration stage mostly resorting to deception farce in order to trick old husbands or fathers, or else foolish, hypocritical coxcombs, and displaying an impressive, skilful use of disguise and impersonation. Behn also turns widely to physical comedy, which is described in detail in stage directions. She appropriates farce in an attempt to please the audience, but also in the service of her own interests as a Tory woman writer.
\end{abstract}

Keywords: Aphra Behn, farce, commedia dell'arte, Restoration England, deception, physical comedy.

\footnotetext{
1 The author wishes to acknowledge funding for his research from the Spanish government (MINECO project ref. FFI2015-68376-P), the Junta de Andalucía (project ref. P11-HUM-7761) and the Xunta de Galicia (Rede de Lingua e Literatura Inglesa e Identidade III, ref. ED431D2017/17).
} 


\title{
"DWINDLING DOWN TO FARCE"?: LA APROXIMACIÓN DE APHRA BEHN A LA FARSA EN LAS DÉCADAS DE 1670 Y 1680
}

\begin{abstract}
RESUMEN. A pesar de sus críticas a la farsa en los paratextos de The Emperor of the Moon (1687), Aphra Bebn utiliza frecuentemente elementos farsescos no solo en esa obra y en The False Count (1681), que se describen como tales en sus títulos, sino también en Sir Patient Fancy (1678), The Feign'd Curtizans (1679) y The Second Part of The Rover (1681). Este articulo sostiene que Bebn adapta la farsa francesa y la commedia dell'arte italiana al teatro inglés de la Restauración principalmente recurriendo a la farsa de engaño para entrampar a viejos maridos o padres, o a personajes necios e hipócritas, exbibiendo una impresionante destreza en el uso de disfraces, y recurriendo a menudo a la comedia física, que aparece descrita detalladamente en acotaciones. Bebn se apropia de la farsa para intentar agradar a la audiencia pero también para servir a sus propios intereses como escritora Tory.
\end{abstract}

Palabras clave: Aphra Behn, farsa, commedia dell'arte, Inglaterra de la Restauración, engaño, comedia física.

Received 24 February 2018

Revised version accepted 26 April 2019

\section{INTRODUCTION}

In the prologue to her play The Emperor of the Moon (1687), Aphra Behn joins other fellow dramatists in presenting farce as a minor genre and a Continental vogue that English playwrights were forced to resort to as a concession to a querulous audience that was otherwise difficult to satisfy. As she puts it, they tried it first with heroic drama, then with satirical comedy, and "Our next Recourse was dwindling down to Farce" (my emphasis. Behn 1996e: 159). ${ }^{2}$ Thus Behn presents this evolution of the audience's taste as degenerative, and farce as less noble than other dramatic genres. Similarly, in the Epistle Dedicatory, she claims that farce is too vulgar and full of buffoonery, that its plots are usually incoherent, and that in The Emperor of the Moon she has endeavoured to adapt the Franco-Italian source to the English theatre and bring it "within the compass of Possibility and Nature" (EM: 157). ${ }^{3}$ Besides, the play is openly presented as a farce also in the title page of the first edition. This is actually a quite spectacular and fanciful piece that merges the traditions of French farce and Italian commedia dell'arte. Yet this is not the only play by Behn that is labelled as a farce. One of the two title pages of The False Count (1681) presents

\footnotetext{
2 All subsequent quotations of this play will be cited parenthetically within the text using the initials $E M$.

3 The source of this play is Nolant de Fatouville's Arlequin empereur dans la lune (1684), which was based on Italian commedia dell'arte.
} 
it as a farce as well, although it is less bizarre than The Emperor of the Moon and, probably for that reason, it is described as "a slight Farce" in its epilogue (Behn 1996d, 355). ${ }^{4}$ Moreover, Behn makes an extensive use of farcical elements in other comedies, particularly in Sir Patient Fancy (1678), The Feign'd Curtizans (1679), and The Second Part of The Rover (1681). This article analyses those elements and contends that Behn criticises farce in her paratexts but resorts to it in many of her texts because she is well aware not only of the audience's tastes but also of the dramatic potentials of deception, disguise, physical humour, the grotesque and stage design. She uses farce in an attempt to attract all types of theatregoers, from the monarch to the lowliest commoner, and also to reinforce the satirical and political aspects of her plays. In them Behn provides plenty of superb, hilarious, farcical moments that demonstrate her mastery of staging and her determination to capitalise on the excellent comedic craft of contemporary actors such as Anthony Leigh, James Nokes, Thomas Jevon, and Cave Underhill.

\section{FARCE IN THE RESTORATION PERIOD}

Although there were many farcical elements in pre-Restoration comedies and drolls, the term farce was not used to describe or classify a certain type of comic play until the early years of Charles II's reign, and the genre started becoming popular in the second half of the 1670s, largely due to the success of, on the one hand, the performances of Italian commedia dell'arte companies at court in 1673 and 1675 and, on the other hand, of Molière's farces, which were translated, adapted and imitated by English playwrights during all that decade. ${ }^{5}$ The influence of the Italian comedies can be seen, for instance, in Ravenscroft's Scaramouch a Philosopher (1677), and that of Molière in that same play, but also in John Lacy's The Dumb Lady (1672), Ravenscroft's The Citizen Turn'd Gentleman (1672), and Otway's The Cheats of Scapin (1676), for example. However, John Dryden and other writers of the period voiced a harsh critique against farce due to its tendency to show extravagant events and monstrous characters, to resort to mimicry and grotesque gestures, and not to conform to the neo-classical rules in general. In his preface to An Evening's Love (1671), Dryden states that he detests the farces that are becoming popular, and differentiates them from what he considers comedy:

Comedy consists, though of low persons, yet of natural actions and characters; I mean such humours, adventures, and designs as are to be found and met with in

\footnotetext{
4 Subsequent quotations of this play will be cited parenthetically within the text with the initials FCo.

5 On farce in general and in Restoration England, in particular, see Albert Bermel (1982), Jessica Davis (2003), Peter Holland (2000), and Leo Hughes (1956). All these scholars highlight its popularity among all social classes.
} 
the world. Farce, on the other side, consists of forced humours and unnatural events. Comedy presents us with the imperfections of human nature. Farce entertains us with what is monstrous and chimerical; the one causes laughter in those who can judge of men and manners, by the lively representation of their folly or corruption; the other produces the same effect in those who can judge of neither, and that only by its extravagances. (Dryden 1973: 353)

Dryden was also disgusted by the success of the Italian companies in England in the early 1670s, which "quite debauched the stage with lewd grimace / Instead of wit and humours, your delight / Was there to see two hobby-horses fight", i.e. Scaramouch and Harlequin (Dryden 1995: 280). Similarly, in his preface to The Womens Conquest (1671), Edward Howard argues that farce is different from comedy, because it simply "consists of Mimikry and other ridiculous Gestures mingled together", tends to be bawdy, and focuses too much on servants who pimp for their masters or mistresses (Howard 1671: sig. b3v). Thomas Shadwell also claimed to dislike farce, although he adapted Molière's work in The Miser (1672), and introduced farcical elements in some of his comedies, particularly in $A$ True Widow (1679). To the latter he added a note to the reader explaining that his intention was "to expose the Style and Plot of Farce Writers, to the utter confusion of damnable Farce, and all its wicked and foolish Adherents" (Shadwell 1679: sig A). And, as we have already seen, Behn also joined this critical discourse against farce, claiming that it is too vulgar, incoherent, and unnatural, different from and inferior to other types of comedy. However, she resorted to Molière quite often for plots and situations in some of her plays, and to characters taken from commedia dell'arte in other pieces. Allegedly, she did so to satisfy audience tastes but, at the same time, she had to adapt farce to "our English Theatre and Genius, who cannot find an Entertainment at so cheap a Rate as the French will, who are content with almost any Incoherences, howsoever stuffed together under the Name of Farce" (EM: 157). ${ }^{6}$

The only open and clear defences of farce that I have found in texts of the Restoration period are the epigram "Of Farces" published by Richard Flecknoe also in 1671, and Nahum Tate's preface to A Duke and No Duke (1693). The former says that "A Farce, is but a merry Play (...) merrier than a comedy by half", making people laugh with mimicking gestures added to comic dialogue (Flecknoe 1671: 52). For Flecknoe there is nothing wrong in laughter, because it is something natural and peculiar to human beings, and he prefers mirth to melancholy. In his preface, Tate seems to find nothing wrong either in its propensity to go beyond probability, to use buffoonery and mimicry, and to follow no strict rules.

\footnotetext{
6 Rebecka Gronstedt (2011: 25) argues that "Behn is torn between her role as a professional dramatist and her position as a poet and critic"; her plays have to satisfy demand, but this jars with her ambition for fame as a respected poet.
} 
Excessive and monstrous fantasy may torment the mind, "but when Extravagancy and Improbability happen to please at all, they do it to purpose, because thy strike our Thought with greatest Surprise" (Tate 1693: sig. C). The actors that play characters such as Harlequin and Scaramouch are experts in physical humour, mimicking, gesticulating, and doing wonderful performances, like mimes. Besides, Tate claims that there is actually farce in many of the best comedies written by Classical, Jacobean, and Restoration dramatists, and that demonstrates that it is not incompatible with good sense or with a satirical purpose.

This more open attitude to farce might be similar to what Behn had as well, in spite of all her lip service criticising it in prefaces and dedications. She was too skilful in devising farcical scenes, and she resorted to them too often in her plays for them to be mere ways to appeal to a larger audience. She was well aware of the powerful comic effect of farce on stage, and she adapted it to her own interests. Behn's comedies show that she was able to write excellent pieces of witty repartee, but also that she had an outstanding knowledge of staging. Dawn Lewcock (1996) claims that Behn's plays are "More for seeing than hearing", due to her sense of spatial relations and her great ability to create comic scenes based on deception, discovery, darkness, and the use of asides. To this let me add Behn's awareness of the superb performing skills of some of the best comic actors of her time. She surely relied on their expertise to act in farcical situations, but her texts often include stage directions describing the gestures and actions the characters are expected to do in those scenes. Behn's command of scenery and performance helped her to appreciate the qualities of farce and to make a successful use of it in many of her comedies. After all, as Susan Carlson (1991: 127) has pointed out, Behn liked challenging the conventions of the theatre, as can be noticeable in her famous lines from the epilogue to Sir Patient Fancy: "Your Learned Cant of Action, Time, and Place, / Must all give way to the unlabour'd farce" (Behn 1996a: 79). ${ }^{7}$ This article will focus on those five plays mentioned above, and will show how, in most of them, Behn combines French-style farce based on deception and disguise, and Italian-style farce of slapstick and physical humour, and how she occasionally resorts to the unnaturalness of the grotesque or the use of fanciful stage setting as well.

\section{DECEPTION FARCE: CHEATING HUSBANDS AND FATHERS}

In Sir Patient Fancy, The False Count, and The Emperor of the Moon, Behn uses a type of deception farce like the one found in previous plays influenced by Molière such as The Dumb Lady, The Cheats of Scapin, or The Citizen Turn'd

Subsequent quotations of this play will be cited parenthetically within the text with the initials $S P F$. 
Gentleman, in which an old, credulous husband or father is cheated by his young wife or daughter, who contrives an extravagant, elaborate trick together with her lover. For example, in Sir Patient Fancy (Dorset Garden Theatre, January 1678), which also draws on several plays by Molière, ${ }^{8}$ and might well be classified as a farce, ${ }^{9}$ the gullible and hypochondriac Sir Patient (played by Anthony Leigh) is duped by his wife (acted by Elizabeth Currer) and her lover Wittmore (Thomas Betterton). And, at the same time, his daughter Isabella (Mary Betterton) is being courted by Lodwick (William Smith). The two plots join in the farcical double bed trick in Act 3, in which Wittmore and Lodwick arrange night meetings with Lady Fancy and Isabella respectively but, in the dark, Lodwick enters Lady Fancy's bedroom and Wittmore goes into Isabella's by mistake. This causes a lot of confusion and reaches its comic climax when Isabella and Sir Patient enter Lady Fancy's bedroom and find Lodwick there, a moment of discovery and surprise that Lady Fancy manages successfully thanks to her wit and to Sir Patient's infatuation with her. And even more farcical is the second bedroom scene, in Act 4. This time Sir Patient surprises his wife with her lover Wittmore. He comes up to the room unexpectedly but Wittmore has time to hide behind the bed. Yet the gallant's clumsy attempts to escape start an excellent scene of bedroom farce, full of physical comedy for which Behn gives plenty of detailed stage directions, and that no doubt displays her dexterous use of farce on stage, as well as the performers' agility. Wittmore pulls a chair down, runs under the bed, and peeps out several times, while Lady Fancy holds her husband in bed, makes signs to her lover to leave the room, and finally:

[Wittmore] Makes signs to her to open the Door: whilst he creeps softly from under the Bed to the Table, by which going to raise himself, he pulls down all the Dressing-things: at the time instant Sir Patient leaps from the Bed, and she returns from the Door and sits on Wittmore's Back as he lies on his Hands and Knees, and makes as if she swooned.

$[\ldots]$

She takes him about the neck and raises her self up, gives Wittmore a little kick behind. (SPF: 58-60)

\footnotetext{
8 The main source of this play is Molière's Le Malade imaginaire (1673), as Gerard Langbaine (1691: 21) already noted. James Halliwell (1860: 230) added Monsieur de Pourceangnac (1669) as a second source; and for Janet Todd (Introduction to SPF: 3-4) there are also echoes of Les Femmes savantes (1672) and L'Amour médicin (1663). See also Ángeles Tomé Rosales (2013) about the comic use of all these sources.

9 Bearing in mind its frequent resort to deception, physical humour, and extravagant characters and situations. In fact, Robert Hume (1976: 328) describes this piece as "a bawdy farce". Yet, it also has elements of sex comedy and political comedy. This is certainly a hybrid play in generic terms, difficult to pigeonhole.
} 
These bedroom farce scenes are full of comic confusion and sexual titillation, mainly to ridicule Sir Patient. For Lewcock (1996: 75), these scenes keep the attention of the audience focused on Lady Fancy's peccadillos and show that she has no scruples about being unfaithful; but it also demonstrates her wit, Sir Patient's dotage on her, his inability to satisfy her sexually, and his foolish hypochondria and Puritanism. ${ }^{10}$ This bedroom farce is certainly crucial in the citcuckolding element of this play, which is so typical of the Tory comedy of the period.

Another farcical scene based on deception in this play that must be mentioned is that of the medical consultation which, according to Janet Todd (SPF: 3), echoes a similar one in Molière's L'Amour médicin (1663). Lodwick and Sir Credulous Easy pretend to be doctors who join a group of four physicians who come to examine Sir Patient. Sir Credulous talks a lot of mambo jambo that includes dog Latin, dog Greek, and misquotes that the other doctors take seriously and join. For instance, Sir Credulous says that Sir Patient suffers, among other things, from vertigo, or "Whirligigoustiphon as the Greeks have it" (SPF: 69), and that he should only eat once in four or five days; and Brunswick adds that Sir Patient must have a dose of his "Merda quecrusticon, or the Amicable Pill" every morning, and sixty restorative pills called "Cheatus Redivivus" after his first sleep (SPF: 72). During the consultation, the quacks drink and quarrel, and the whole scene is full of comic incongruity and nonsense, making fun of both Sir Patient and Sir Credulous, and satirising the obscurity of medical jargon and the medical practice of the time.

In the case of The False Count, Or, A New Way to Play and Old Game (Duke's Theatre, October or November 1681), as was said above, one of the two title pages of the first edition presents it as A Farce Call'd The False Count. ${ }^{11}$ Besides, the term is also used by Don Carlos at the beginning of Act 4, scene 2: "I'll retire then, and fit me for my part of this Farce" (FCo: 338), referring to the prank that he has prepared. Furthermore, in the epilogue, the piece is described as "a slight Farce". The anonymous author of this epilogue also suggests that Behn has attempted to please the audience by offering them what they seem to like most: the foolish

\footnotetext{
10 As Douglas Canfield (1997: 146-147) has noted, Lady Fancy is an example of witty female trickster of Restoration comedy. She has married a foolish old cit for money but continues having sex with her lover Wittmore, who is a rakish gallant but not as witty as her. She manages to escape every near disaster, knows how to manipulate her doting, hypochondriac husband, and ends up separating from him with a considerable portion of his money. For Robert Markley (2004: 205), she is a pragmatist and an example that Behn's heroines are usually smarter than their lovers. Sue Crowson (2000: 185-187) also highlights Lady Fancy's determination in asserting herself sexually and her witty manner of cheating her husband and saving her skin when she is in a tight spot.

${ }^{11}$ For a previous analysis of farce in The False Count, see Figueroa Dorrego (2015).
} 
buffoonery and crude practical joking of farce instead of the sense and wit of comedy. The play certainly features typical elements of farce, such as disguise, trickery, and ingenious lower-class characters.

For the plot, Behn most likely drew ideas from French texts such as Molière's Les Précieuses ridicules (1659) and Les Fourberies de Scapin (1671), and maybe also Antoine Montfleury's L'École des jaloux ou le cocu voluntaire (1664). The False Count mainly revolves around two practical jokes, one of which is contrived by a witty servant called Guzman (Underhill), in order to help his master Don Carlos, Governor of Cadiz, recover the woman he loves, Julia, who has been forced to marry an old, jealous upstart called Francisco (Nokes). In spite of his Spanish name, Francisco is originally an English shoemaker who managed to become a gentleman in a dubious manner. He keeps his new wife "as close as a Relict, jealous as Age and Impotence can make him" (FCo: 306) and is a rather unsavoury character somehow reminiscent of Pinchwife in William Wycherley's The Country Wife (1675). When Francisco is sailing with his wife near Cadiz, he is tricked to believe that some Turks assault the ship and intend to take it to their country, although they simply sail for a few miles further. The scenes of this hoax are quite ludicrous because the old jealous man gets so panic-stricken at the possibility of his being castrated and Julia being ravished by the Turks, that he is unable to fight in order to defend himself and his wife. Besides, he is too stingy to be willing to pay a ransom. So it is easy for Don Carlos, who is disguised as a Turkish sultan, to make Francisco resign Julia to him in exchange of his life and freedom. Francisco even urges Julia not to reject the Grand Signior: "go prethee Hony go - do me the favour to Cuckold me a little, if not for Love, for Charity" (FCo: 348). Thus the old husband, who was earlier so anxious about his wife's possible infidelity is seen paradoxically promoting his own cuckoldry, and this way he is shamefully exposed and humiliated onstage. ${ }^{12}$

As argued in Figueroa Dorrego (2015: 87), this plot line consists of a plot (in the sense of stratagem) against a social-climbing cit who proves to be no real or ideal gentleman. Moreover, it is interesting to point out that Don Carlos considers Francisco's marriage to Julia as a sort of usurpation. In the final scene, he claims that she belonged to him: "she was my Wife in sight of Heav'n before; and I but seiz'd my own" (FCO, 353). Usurpation is a recurrent motif in Restoration drama for obvious reasons. And, as other middle-class characters satirised in Tory comedies of the time, Francisco is parsimonious, sexually impotent, cowardly, and hypocritical; and as a parvenu he is finally put back in his place by a worthy nobleman (see

\footnotetext{
${ }^{12}$ Behn's use of Turkish outfits in this play is reminiscent of Ravenscroft's in The Citizen Turn'd Gentleman, in which Cleverwit disguises as the Great Turk in order to marry Lucia, and he pretends to make her old father Mr Jorden a noble "mamamouchi" if he converts to the Muslim religion.
} 
"DWINDLING DOWN TO FARCE"?: APHRA BEHN'S APPROACH TO FARCE...

also Canfield 1997: 180-181). Bearing in mind Behn's usual anti-Whig partisanship and the idea of a make-believe trick, it is possible to relate this fictional plot based on social aspirations, false appearances, and religious prejudices to the Popish Plot of 1678-81 (see also Ballaster 1996).

In The Emperor of the Moon: A Farce (Queen's Theatre, 1687), ${ }^{13}$ Behn uses deception farce in the main plot, in which Doctor Baliardo (Underhill), a man obsessed with the observation of the moon and the privacy of the lunar monarch, is tricked by Cinthio and Charmante, the viceroy's nephews, so that they can court his daughter Elaria and his niece Bellemante respectively. ${ }^{14}$ For this purpose the young gallants count on the help of Doctor Baliardo's servant Scaramouch. It is him who informs Elaria at the very beginning of the play that they are preparing "a Farce, which shall be called, --- The World in the Moon", and will be acted in the doctor's own house (EM: 163). The farce consists in making him think that with sexual abstinence he can see people who live in "the vast Region of the Air" (EM: 166), and that the Emperor of the Moon and the Prince of Thunderland are in love with Elaria and Bellemante, and will come to ask for their hands in marriage with his consent. Obviously, the credulous doctor believes and approves it enthusiastically, and the lunar aristocrats are actually Cinthio and Charmante, who thus manage to enter Doctor Baliardo's house, meet their beloved, and wed them finally. At the end they tell him that they mounted all that show in order to cure him of his lunacy, that "These Stories are the Fantoms of mad Brains", "Rediculous Inventions", designed to finally open his eyes (EM: 205). ${ }^{15} \mathrm{He}$ then determines to have all his books burned and to abandon his pseudo-scientific follies. This deception farce poking fun at the foolish virtuoso has elements of scientific and political satire (see Al Coppola 2008 and Florence March 2006), and is reinforced with slapstick, music, dancing, and a striking mise-en-scène, as will be shown later. This way Behn cleverly integrates the social and the metatheatrical, while offering a grand comic spectacle. ${ }^{16}$

\footnotetext{
13 This play was probably drafted about 1684 but not performed until three years later for financial reasons, and that is quite noticeable in its political message. As Coppola (2008: 493) has pointed out, a play ridiculing a credulous virtuoso and his appetite for improper discoveries would have made more sense in 1684 , when the Tories were trying to defuse the enthusiasm for plots. Nevertheless, it was very successful and remained so during the first half of the eighteenth century, most likely because the audience preferred to enjoy it as a farcical spectacle rather than a political play.

${ }_{14}$ Doctor Baliardo's looks are already quite ludicrous: in Act 2, scene 2 he appears with mathematical instruments hanging at his girdle, and with his servant Scaramouch carrying a telescope 20 feet long. Besides, March (2006: 110) claims that the name Baliardo comes from the Italian word balordo, which means stupid.

15 Davis (2003: 91-95) distinguishes between humiliation and deception farces. The former subject their victims to explicit degradation, whereas the latter make the butts be blind to the fact that they are being outwitted, but some kind of reconciliation is finally sought by the practical jokers.

${ }^{16}$ As Steven Henderson (2000: 62) puts it, "Behn uses the familiar deception-farce model in order
} 


\section{DECEPTION FARCE: DERIDING FOOLS AND HYPOCRITES}

Sometimes the butts of the deception are foolish hypocritical characters instead of husbands or fathers. This can be seen in Sir Patient Fancy, The Feign'd Curtizans, Rover II and the second plot of The False Count. For instance, in the former play, many of the farcical aspects are present in some scenes in which Sir Credulous Easy is involved. He is a gullible, simple-minded man, who becomes an easy prey to Lodwick's pranks. Lodwick, although one of the gallants of the play, undertakes the role of a trickster, attempting to ridicule the provincial knight and ruin his courtship of Lucretia. This leads to several farcical scenes, such as the one in which Lodwick convinces Sir Credulous to pretend to be a dumb ambassador from the god of love, who communicates with sign language that Lodwick will interpret for Lucretia to understand. Sir Credulous starts making weird signs and grimaces, which Lodwick interprets the wrong way on purpose, attempting to make the knight give valuable objects such as diamond rings, gold, and a hieroglyphic watch to Lucretia. Sir Credulous does not like Lodwick's interpreting at all but, obviously, he cannot speak out to correct him without ruining his impersonation. Leander metadramatically refers to these ludicrous tricks played on Sir Credulous as "Farce" (SPF: 17), which is one based on deception, derision, and dramatic irony. ${ }^{17}$ Lodwick continues ridiculing Sir Credulous by suggesting him to try to surprise Lucretia with an extravagant serenade. So Sir Credulous appears riding an elephant and leading a group of raucous musicians to the door of Lucretia's house, starts singing a foolish love song, but he is soon beaten up by a servant. This is an impressive scene that intends to shock the audience with its extravagance and incongruity, and that proves Behn's daring and skilful dramatic techniques and her commitment to farce. ${ }^{18}$

In The Feign'd Curtizans, or, A Nights Intrigue (Dorset Garden Theatre, about March 1679) Behn resorts to disguise, darkness, and physical humour in order to raise the audience's laughter; and she maintains her interest in social and political satire but mostly returns to comedy of intrigue à la Rover. The play was premiered with an impressive cast that included Betterton, Smith, Nokes, Underhill, Barry, and Currer among others. The decision of two young sisters, Marcella and Cornelia, from a noble Italian family, to pass off as courtesans in order to escape from an

\footnotetext{
to foster the audience's awareness of the duality of the worlds of the play and the playhouse, the imaginative theatrical space and the social space of the theatre."

${ }^{17}$ Juan A. Prieto-Pablos argues that comic effects are based on the audience's privileged position with respect to the information offered from the stage, depending to a large extent on a discrepancy between what some characters (mostly the dupes) fail to be aware of and what others (the tricksters) and the audience know. Lack of awareness entails lack of control of the situation and this makes the dupes ridiculous (2005: 70-71).

${ }^{18}$ For Michael Peterson, this is the peak of Sir Credulous's ridiculous efforts and "the point at which Behn's physical dramaturgy reaches its greatest depth" (2007: 36).
} 
unwanted fate (arranged marriage and monastic life respectively, like Florinda and Hellena in The Rover) causes a lot of confusion and misunderstanding that complicate the plot and generate several humorous situations. This is even made more intricate when they disguise as men in certain scenes as well, and also because Marcella calls herself La Silvianetta when she feigns to be a courtesan, and that is the same name that another character, Laura Lucretia, adopts in order to conceal her real identity from Count Julio, to whom she is engaged. Laura also crossdresses hoping to get closer to her beloved Galliard, who loves Cornelia. As Jane Spencer (1993: 95ff) has argued, the three women adopt multiple disguises and resort to deception through necessity. Gender restrictions and subordination make them turn to dissembling and trickery if they want to achieve their desires. Marcella and Cornelia's impersonation of courtesans is potentially risky but with it they paradoxically manage to preserve their chastity and marry the gallants they love: Fillamour and Galliard. Pilar Cuder Domínguez (1997: 130) claims that Behn presents this - somehow farcical - masquerade of the young noblewomen feigning to be courtesans in order to remind us that all women are in some way reified and commodified, an idea quite often present in her plays.

Yet, most of the farce in The Feign'd Curtezans is found in the subplot, provided by the sisters' protean servant Petro (Leigh). He is a roguish character that impersonates different identities in order to cheat the foolish Sir Signall Buffoon (Nokes) and his tutor Mr Tickletext (Underhill). Petro is a clever and versatile trickster, and the other main initiator of action apart from the female characters mentioned above. Tickletext is an old, hypocritical, Puritan chaplain who still believes himself attractive to women. He is a bigoted anti-Catholic who, at the same time, is fascinated with Romish finery and is willing to profit from Roman licentiousness. ${ }^{19} \mathrm{He}$ is the main comic butt of this comedy and his disparagement represents the major political aspect of the play, which is the first that Behn wrote after the advent of the Popish Plot. ${ }^{20}$

In one of the scenes, Petro passes himself off as a barber attending to Tickletext and makes horns and grimaces behind him while the chaplain is looking

\footnotetext{
19 Todd (1996: 245) posits that he is "a clear Oates-ish figure" with whom Behn intends to "mock the nationalism of Protestant Dissent which breeds fear, as opposed to the easy internationalism of Catholicism." Todd explains that Oates had also travelled in Catholic Europe, was taken with Catholic luxury while condemning it in others, and had later invented the Popish Plot. She also sees parallelisms between Tickletext and Hugh Peters, who was famous in the Interregnum for his raving sermons and his lasciviousness (introduction to FC: 84-85).

20 Susan Owen (1996: 17-18) reminds us that "[i]n the Exclusion Crisis, patriotism and hostility to the influence of Popish countries were weapons in the Whig arsenal", and she argues that satire of Tickletext is "satire of the Protestant, mercantile middle class" and of the "prevailing mentality in 1679 , as seen by royalists". And Alison Shell (1996: 42) adds that Behn's anti-Dissent satire in this play is "not only pro-Tory but pro-Catholic".
} 
proudly to himself in the mirror. He later pretends to be a French fencing master, and we can see Tickletext undressing himself, intending to fight in ridiculous postures, and beating Petro about the stage. Shortly after that, there is a fight and Sir Signall cowardly climbs a tree and his tutor "runs his head in a bush, and lies on his hands and knees" (Behn 1996b: 108). ${ }^{21}$ Morever, feigning to be a civility master, Petro teaches the foolish Englishmen how to salute a person of quality, so they start bowing repeatedly. He also encourages them to take snuff, which they do not like much so they sneeze and make grimaces; and he teaches them to give presents and thus he gets a ring and a gem; and the final lesson is to tell a story without words, so he makes signs, mimes actions, picks their pockets, and hits their faces. The Feign'd Curtizans is full of farcical action aiming at exposing and ridiculing the two English fools. We will deal with more instances in a later section that focuses on physical humour.

Moving now to The Second Part of The Rover (Dorset Garden Theatre, January 1681), this is supposed to continue the adventures of Willmore, the protagonist of The Rover (1677) but this time in Madrid, and without Hellena, who has recently died, and Belvile, who is married and living in Paris. Willmore (again Smith) is still a rake, but no longer so lively and appealing. He seems in a darker mood, more "Satyrical" (Behn 1996c: 233), ${ }^{22}$ and focusing his actions on two aims: (re) gaining the love of the courtesan La Nuche (Barry, who had played Hellena in Rover I) and duping the two fools of this play: Ned Blunt (already in Rover I, and again Underhill) and Nicholas Fetherfool (Nokes). The coxcombs plan to marry two Jewish women who are of unusual size (a giant and a dwarf), mainly because of their wealth (£100,000 each), and because they are told that there is a mountebank who can "reform" them. When these fools attend to the charlatan's show, Behn gives detailed stage directions of the display: a pageant enters the stage, with music and dancing; Willmore is dressed as a mountebank, Harliquin (Richards) is assisting him, and Blunt and Fetherfool are among the onlookers below. Willmore says his elixir can cure "the Distempers both of Mind and Body" (RII: 248) and even revive a dead body. To show it, Harliquin pretends to stab himself, fall dead, and rise again after having the elixir. Besides, in this same scene, Harliquin manages to steal Don Carlo's horse while he is on the saddle, leaving him perplexed and furious, in a very farcical jest. Fetherfool is also the butt of a farcical scene when he is waiting for La Nuche and Don Carlo comes in, holds his hand and kisses him until they realise the mistake and start fighting. Likewise when he steals Giant's pearls but does not know how to hide them, and ends up

\footnotetext{
${ }^{21}$ Subsequent quotations of this play will be cited parenthetically within the text, with the initials $F C$. ${ }^{22}$ Subsequent quotations of this play will be cited parenthetically within the text, with the initials RII. The Rover will be referred to as Rover I.
} 
swallowing them at Harliquin's suggestion. ${ }^{23}$ As he hears people coming, he gets into a clock case, again following the instructions of Harliquin, who "Ig/oes into the Case and shows him how to stand; then Fetherfool goes in, pulls off his Periwig, his Head out turning for the Minutes o'th'top: his Hand out, and his Finger pointing to a Figure" (RII: 290). When Shift sees something strange in the clock, Fetherfool blows out his candle and gets away with Giant while Harliquin "plays tricks" with Shift in the dark (RII: 291). This time there are no directions describing those tricks and, therefore, the actor is free to improvise.

Finally, as regards this section, the second plot of The False Count revolves around Francisco's daughter from a former wife, Isabella, who rejects Antonio as a suitor because she considers him a "base Mechanic" (FCo: 307) and "a little, dirtyheel'd Merchant" (313), who presumptuously aims to marry her. However, Antonio is the worthy son of a rich merchant and a good friend of Don Carlos. He is never portrayed as a fool, whereas the haughty arriviste Isabella is, and she consequently becomes the butt of the second practical joke in the play. As Antonio wishes to revenge her despise, Don Carlos proposes to dupe her making a chimney sweep pose as a count that will court Isabella. ${ }^{24}$ The importance given to this character, called Guiliom, is evident because he is the false count referred to in the title, but also because his role was given to Anthony Leigh in the premiere. In spite of some funny blunders and untimely use of his trade's vocabulary, Guiliom manages to pass off as Don Guilelmo Roderigo de Chimeny-swiperio successfully, persuading Isabella and her father that he is a real count worthy of marrying her. However, when the truth is revealed, Isabella feels disappointed at finding out that she is no real countess, and thus becomes the second victim of the ruses in this Molièresque "slight farce".

\section{PHYSICAL COMEDY}

Behn uses physical comedy in all the plays analysed here to a larger or lesser extent, and often describes it in detail in stage directions. We have already seen it in the bedroom farce in Sir Patient Fancy, Petro's tricks to Tickletext, and Harliquin's to Fetherfool, but there are many more examples that should be mentioned here. For instance, in Act 3 of The Feign'd Curtizans, Tickletext goes to meet the famous

\footnotetext{
23 According to Heidi Hutner (1993: 116-117), Fetherfool's act of devouring Giant's pearls is a symbolical manner of devouring her. However, Giant's pearls symbolise her wealth rather than her body, because it is her wealth that Fetherfool desires, not her body, which is too big and threatening for such a petty man.

${ }^{24}$ Impersonating members of the nobility is common in farces of this period, from Ravenscroft's The Citizen Turn'd Gentleman to Tate's A Duke and No Duke and Jevon's The Devil of a Wife. As PrietoPablos (2005: 73) has pointed out, these plays toy with the projection of the fantasy of becoming someone of the upper class.
} 
prostitute Silvianetta in the dark but he bumps into Octavio, who beats him up repeatedly. Then enters Sir Signall with a masquerade coat and a lantern advancing softly, groping with his hands, until he feels the point of Octavio's sword and runs away. Behn describes the movements of the characters on stage thoroughly, as when Sir Signall stumbles on his tutor, who comes from the opposite side:

They both advance softly, meeting just in the middle of the Stage, and coming close to each other! both cautiously start back: And stand a tipto in the posture of Fear, then gently feeling for each other, (after listening and hearing no Noise) draw back their Hands at touching each other's, and shrinking up their Shoulders, make grimaces of more Fear! (FC: 123)

Directions like this evince that Behn had a very clear idea of what she wanted to be performed on stage. The scene finishes with another fight while some musicians are playing, in which "Galliard loses bis sword, and in the burry, gets a Base Viol, and happens to strike Tickletext, who is getting away-bis head breaks its way quite through, and it hangs about his neck" (FC: 125). So, Behn moves swiftly from mild physical comedy to a moment of potentially serious violence, which ends in slapstick aggression. Derek Hughes (2001: 110) suggests that "the farcical slapstick perhaps satirizes the more menacing acts of male violence".

Tickletext is the butt of further farcical ridicule in Act 4, when he meets Galliard unexpectedly in the dark and kisses him thinking he is with La Silvianetta. Again stage directions describe the action in detail: Tickletext struggles to get away, Galliard holds him by the cravat and periwig, Petro unties the chaplain's cravat and slips his head out of the periwig trying to take him away, they run over the stage, and Galliard goes after them with the cravat and periwig in one hand and a pistol in the other.

Tickletext struggles to get away, [Galliard] holds him by the Cravat and Periwig.

[...]

Petro puts out the Candle, comes to Tickletext, unties his Cravat behind, and he slips his head out of the Periwig and gets away, leaving both in Galliard's hands.

[...]

[Enter] PETRO with TICKLETEXT running over the stage, GALLIARD after'em, with the Cravat and Periwig in one hand, his Pistol in t'other. (FC: 134).

The scene continues with Sir Signall running on stage too and hiding in a fireplace because a shot is heard. He then keeps peeping out to see when he can come out, his face becoming more and more sooty, until he is found and kicked out by Galliard. Physical comedy is seen again when in the following act, still in darkness, Tickletext stumbles at a well and slides down in the bucket. When Sir Signall comes to wash his face and pulls the bucket, he sees someone coming 
up inside so he runs away frightened. They happen to meet again, unknowingly, later in a room of what Sir Signall quixotically believes to be the enchanted castle of a giant. As they hear people coming, Tickletext hides behind a curtain and Sir Signall creeps in too behind him. They peep out at the end of the play causing the gallants' laughter, and supposedly the audience's too. The comic skills of the cast no doubt guaranteed an excellent performance of all these farcical scenes. The devastating mockery of Tickletext is one of the most powerful satires against Puritans and anti-Catholic fanatics created by Behn. However, in spite of all the attempts to make the audience laugh with the use of deception farce and physical comedy, the reception of this play was not as favourable as expected, most likely due to the tense political context in 1679 London.

In The Emperor of the Moon, Harlequin (Jevon) and Scaramouch (Leigh), servants to Cinthio and Doctor Baliardo respectively, often engage in absurd and slapstick actions that intend to raise the audience's laughter. For instance, Harlequin says he wants to kill himself because he thinks his beloved Mopsophil has betrayed him, but he wishes to do it in an original way, so he determines to laugh to death by tickling all his body, making funny sounds and laughs, and strange leaps until he falls down apparently dead. In another comic scene, Harlequin cheats an officer who stops his calash and wants him to pay for his load. As Harlequin hits him, the officer goes to get a clerk and, meanwhile, Harlequin changes the appearance of the calash, and then accuses the officer of being drunk and demands monetary compensation. Yet most slapstick takes place when Harlequin interacts with Scaramouch, as happens when in Act 1, scene 3 they are hidden, waiting for a chance to be with Mopsophil, Harlequin accidentally hits a table and this triggers a series of ludicrous postures and faces, groping, biting, and creeping under the carpet. When Mopsophil arrives, Harlequin peeps under a table and falls at her feet. Then the two rivals start fighting in a ridiculous manner but end up dancing and shaking hands. They make funny movements and grimaces, and engage in "a ridiculous cowardly Fight" (EM: 195) later when they both propose marriage to Mopsophil unsuccessfully and are finally beaten up and cast out from Doctor Baliardo's house. Harlequin and Scaramouch are clearly borrowed from the Italian commedia dell'arte, in which physical lazzi were common. ${ }^{25}$

\section{GROTESQUE AND MACHINE FARCE}

Behn's mastery of staging is not only evidenced by her carefully directing the performance of the most skilful comic actors of the time. She had a talent

\footnotetext{
${ }^{25}$ Lazzi were - mostly physical - comic gags that mixed stock routines and improvisation, and were frequently used in commedia dell'arte.
} 
for visual comedy and also for spectacle on stage. We have seen before how she dares strike the audience by introducing an elephant on stage. Behn sometimes produces farce by resorting to the grotesque and to imposing stage setting. The abovementioned Jewish female "Monsters" of Rover II are an example of how she uses the grotesque to create ludicrous scenes but also to combine it with sympathetic feelings. These characters also exist in Behn's source, Thomas Killigrew's Thomaso, or The Wanderer (1654), but they are never seen, only mentioned, and they are rather abused. However, Behn shows them on stage and does so with sympathy and dignity, using them to ridicule Blunt and Fetherfool instead. The "Monsters" are very deviant, exotic characters that not only have bodies of unusual size but are also alien in terms of religion and nationality, because they are Jews coming from Mexico. One is so small and deformed that "she is not capable of marriage", and the other is so huge that "no man dares venture on her" (RII: 237). The meeting of the English coxcombs with the Jewish "Monsters" is really ludicrous. When Fetherfool sees Giant, he is shocked, compares her to the Whore of Babylon, Saint Christopher's image in Notre Dame, and Gargantua, and himself to Hercules humiliated in front of Omphale. Shift sets a ladder against Giant and asks Fetherfool to climb and greet her; but she proudly rejects him as a suitor because she will marry "none whose Person and Courage shall not bear some proportion to mine", to which he answers: "Your Mightiness, I fear, will die a Maid then" (RII: 258). Symbolically speaking, this obviously elevates her, belittles Fetherfool, and vindicates her right to find an equal as a partner. ${ }^{26}$ Then Hunt enters disguised as a giant as if he were a suitor to Giant and, when he leaves, the door is too small so he divides himself in two. The stage direction explains how this is to be done: "Hunt being all Doublet, leaps off from another Man who is all in Britches, and goes out, Britches follows stalking" (RII: 261). This frightens the cowardly and dim-witted Fetherfool, but intends to raise a hearty laughter in the audience at his expense. Farce is used here not only to ridicule a fool but also to empower the Jewish female "Monsters", who demand freedom and equality in the choice of husband, and are not economically or physically abused.

Finally, in The Emperor of the Moon, the last fight between Harlequin and Scaramouch is included in the machine farce of the final scene, in which there is an impressive display of scenery resources. The scene shows a large walk in the Hill of Parnassus with several negroes on pedestals and Keplair and Gallileus descending in chariots on each side, then a huge zodiac comes down, persons

\footnotetext{
${ }^{26}$ For Jacqueline Pearson (1996: 222-223), “The 'Monsters' provide grotesque comedy in keeping with the harlequinade element in the play, but more seriously they are also allowed to suggest the monstrousness of a system of money in which women attain significance only in terms of their financial value". For a study of this scene in relation to the grotesque, see Ángeles Tomé Rosales (2009).
} 
representing the twelve signs sing, and the negroes dance. After that appears a chariot made like a half moon, with Cinthio and Charmante disguised as the Emperor of the Moon and the Prince of Thunderland. They make signs of love in dumb show to Elaria and Bellemante, and then a stentraphon says they have come to wed the young ladies. There are hymeneal songs and a priest who joins the lovers' hands. This marriage ceremony is interrupted by Harlequin and Scaramouch in this manner:

two Chariots descend, one on one side above, and the other on the other side; in which, is HARLEQUIN dress'd like a Mock Hero, with others, and SCARAMOUCH in the other, dress'd so in Helmets.

[...]

They both, all arm'd with gilded Lances and Shields of Black, with Golden Suns painted. The Musick plays a fighting Tune. They fight at Barriers, to the Tune. ---Harlequin is often Foil'd, but advances still; at last Scaramouch throws him, and is Conqueror; all give Judgment for him. (EM: 205-205).

As a consequence, Doctor Baliardo gives Mopsophil's hand to the winning knight and finds out he is Scaramouch, the old man bawls out and falls in a chair, feeling himself cheated. With this bathos ends this masque-like scene and the whole bizarre farce devised by the young gallants to trick the credulous virtuoso and marry their sweethearts. And this is also how Behn transforms a combination of deception farce and commedia dell'arte into a stunning spectacle that enthralled audiences for several decades.

\section{CONCLUSION}

It seems quite evident that Behn makes an extensive and successful use of farce in many of her plays of the late 1670s and the 1680s, particularly in Sir Patient Fancy, The Feign'd Curtizans, The Second Part of The Rover, The False Count, and The Emperor of the Moon. In all of them she includes some kind of deception farce, like the one found in previous plays influenced by Molière. Normally, in this type of farce, an old, foolish, gullible husband or father is tricked by his young wife or daughter and her lover, who contrive an extravagant, elaborate prank (often referred to as "farce" in the plays) that exposes and takes advantage of the victim's delusion. This is seen in Sir Patient Fancy, The False Count, and The Emperor of the Moon. Other times, the butts of the deception are fools or hypocrites, such as Sir Signall and Tickletext in The Feign'd Curtizans, Ned Blunt and Fetherfool in Rover II, and Isabella in The False Count, who become easy preys to witty tricksters such as Petro, Willmore, Harlequin, and Guiliom. In all these cases there is an extensive, impressive, skilful use of disguise and impersonation, and the audience 
is placed in a privileged position that produces laughter at the expense of the butts of the pranks. Moreover, in all the plays analysed here, except perhaps in The False Count, Behn resorts to physical comedy, which is described in detail in stage directions. Sometimes it is in the form of slapstick, but it is mostly done through ridiculous gestures and comic scenic movement. This physical comedy appears in scenes of bedroom farce in Sir Patient Fancy, The Feign'd Curtizans, and Rover II, as they are more influenced by the vogue for sex comedy that dominated the 1670s. In Rover II and The Emperor of the Moon, Behn introduces characters such as Harlequin and Scaramouch, who come from the tradition of Italian commedia dell'arte and engage in both tricks and physical humour. Besides, in Rover II, she creates farcical scenes around the grotesque figures of the two Jewish female "Monsters", and in The Emperor of the Moon, she does it with a striking, extravagant mise-en-scene in the last act. No doubt Behn was one of the main practitioners of farce in the Restoration period.

Therefore, when Behn criticises farce in her paratexts, she is simply paying lip service to the prevailing discourse against this genre, so her claim to be "dwindling down" to it only to please the audience is rather an attempt to please the critics. She seems to enjoy creating farcical scenes full of physical humour and extravagant actions, and to be aware of the powerful comic effect they have on stage, not only in order to surprise the playgoers and raise their laughter, but also to reinforce the social and political critique in her comedies. ${ }^{27}$ In most cases, Behn inserts farce in plays that have the dramatic structure of five acts with preface and epilogue that was common in Restoration comedy, in order to deal with cit-cuckolding, deception, and disguise, and to ridicule fops and hypocritical Puritans. Only in The Emperor of the Moon does she use a structure of three acts typical of contemporary farces, but she includes a whole set of paratextual material. Behn takes advantage of the excellent performing abilities of the best comic actors of the time, such as Jevon, Leigh, Nokes, and Underhill, as well as of her own mastery of staging, so as to provide excellent, hilarious, farcical scenes in those plays. The extensive use of stage directions that explain in detail the situations and the actions to be performed prove that Behn had a clear idea of those ludicrous scenes in her mind and did not want to leave much room to improvisation. So here farce is not only actors' theatre, but to a large extent also author's theatre. ${ }^{28}$ Behn was a complete dramatist, with a keen mind for comedy, able to write witty repartee and intelligent dialogues, but also to design entertaining plots full of intrigue and comic scenes. That is, she was talented for both the visual and verbal elements of comedy. Behn does not seem to have dwindled down to

\footnotetext{
${ }^{27}$ This would contradict Davis's claim that farce avoids social criticism and satirical comment (2003: 141).

${ }^{28}$ Holland (2000: 109) states that farce is actor's theatre. Similarly, Bermel (1982: 56) claims that it is "primarily a performer's art, not a writer's".
} 
"DWINDLING DOWN TO FARCE”?: APHRA BEHN'S APPROACH TO FARCE...

farce reluctantly, but rather appreciating its value and adapting the French and Italian traditions to the English stage and to her own interests as a Tory woman writer.

\section{REFERENCES}

Ballaster, R. 1996. "Fiction feigning femininity: false counts and pageant kings in Aphra Behn's Popish Plot writings". Aphra Behn Studies. Ed. J. Todd. Cambridge: Cambridge University Press. 50-65.

Behn, A. 1996a (1678). Sir Patient Fancy. The Works of Aphra Behn. Vol. 6. The Plays 1678-1682. Ed. J. Todd. London: William Pickering. 1-81.

Behn, A. 1996b (1679). The Feign'd Curtezans. The Works of Aphra Behn. Vol. 6. The Plays 1678-1682. Ed. J. Todd. London: William Pickering. 83-159.

Behn, A. 1996c (1681). The Second Part of The Rover. The Works of Aphra Behn. Vol. 6. The Plays 1678-1682. Ed. J. Todd. London: William Pickering. 223-298.

Behn, A. 1996d (1681). The False Count. The Works of Aphra Behn. Vol. 6. The Plays 1678-1682. Ed. J. Todd. London: William Pickering. 299-356.

Behn, A. 1996e (1687). The Emperor of the Moon. The Works of Aphra Behn. Vol. 7. The Plays 1682-1696. Ed. J. Todd. London: William Pickering. 153-207.

Bermel, A. 1982. Farce. A History from Aristophanes to Woody Allen. New York: Simon and Schuster.

Canfield, D. 1997. Tricksters and Estates: On the Ideology of Restoration Comedy. Lexington: University Press of Kentucky.

Carlson, S. 1991. Women and Comedy. Rewriting the British Theatrical Tradition. Ann Arbor: University of Michigan Press.

Coppola, A. 2008. "Retraining the Virtuoso's Gaze: Behn's Emperor of the Moon, the Royal Society, and the Spectacle of Science and Politics". Eighteenth-Century Studies 41 (4): 481-506.

Crowson, S. 2000. "Mother, Stepmother, and the Mother Tongue: Women Beyond the Grotesque in Aphra Behn's Sir Patient Fancy". Aphra Behn (1640-1689): Identity, Alterity, Ambiguity. Eds. M. A. O'Donnell, B. Dhuicq and G. Leduc. Paris: L'Harmattan. 183-189.

Cuder Domínguez, P. 1997. "Pretty Contradictions': The Virgin Prostitutes of Aphra Behn's The Feigned Courtesans (1679)”. SEDERI 8: 129-133.

Davis, J. M. 2003. Farce. New Brunswick: Transaction.

Dryden, J. 1973. "Preface to An Evening's Love: or, The Mock Astrologer". Restoration and Eighteenth-Century Comedy. Ed. S. McMillin. New York: Norton. 352-360. 
Dryden, J. 1995. "Prologue and Epilogue at Oxford, 1673". The Poems of John Dryden. Vol 1. 1649-1681. Ed. P. Hammond. London: Routledge. 277-281.

Figueroa Dorrego, J. 2015. “'Zounds, what Stuff's here?' The 'slight Farce' of Aphra Behn's The False Count'. English and American Studies in Spain: New Developments and Trends. Eds. A. Lázaro Lafuente and M. D. Porto Requejo. Alcalá de Henares: Universidad de Alcalá. 84-90.

Flecknoe, R. 1671. "Of Farces". Epigrams of All Sorts, Made at Several Times on Several Occasions. London: Printed for the Author. 52.

Gronstedt, R. 2011. "Aphra Behn and the Conflict Between Creative and Critical Writing”. Aphra Bebn and her Female Successors. Ed. M. Rubik. Vienna: Lit Verlag. 21-37.

Halliwell, J. O. 1860. A Dictionary of Old English Plays. London: John Russell Smith. Henderson, S. 2000. “"Deceptio visus”: Aphra Behn's Negotiation with Farce in The Emperor of the Moon". Aphra Behn (1640-1689): Identity, Alterity, Ambiguity. Eds. M. A. O'Donnell, B. Dhuicq and G.Leduc. Paris: L'Harmattan. 59-66.

Holland, P. 2000. "Farce". The Cambridge Companion to English Restoration Theatre. Ed. D. Payne Fisk. Cambridge: Cambridge University Press. 107-126.

Howard, E. 1671. The Womens Conquest: A Tragi-Comedy. London: H. Herringman. Hughes, D. 2001. The Theatre of Aphra Behn. Basingstoke: Palgrave.

Hughes, L. 1956. A Century of English Farce. Princeton: Princeton University Press. Hume, R. D. 1976. The Development of English Drama in the Late Sixteenth Century. Oxford: Clarendon Press.

Hutner, H. 1993. "Revisioning the Female Body: Aphra Behn's The Rover, Parts I and II". Rereading Aphra Behn. History, Theory, and Criticism. Ed. H. Hutner. Charlottesville: University Press of Virginia. 102-120.

Langbaine, G 1691. An Account of the English Dramatick Poets. Oxford: George West and Henry Clements.

Lewcock, D. 1996. "More for seeing than hearing: Behn and the use of the theatre". Aphra Behn Studies. Ed. J. Todd. Cambridge: Cambridge University Press. 66-83.

March, F. 2006. "Farce, satire et science dans The Emperor of the Moon (1678) d'Aphra Behn". Études Épistémè 10: 99-115.

Markley, R. 2004. "Behn and the unstable traditions of social comedy". The Cambridge Companion to Aphra Bebn. Eds. D. Hughes and J. Todd. Cambridge: Cambridge University Press. 98-117.

Owen, S. 1996. "Sexual politics and party politics in Behn's drama, 1678-83". Aphra Behn Studies. Ed. J. Todd. Cambridge: Cambridge University Press. 15-29. 
Pearson, J. 1996. "Slave princes and lady monsters: gender and ethnic difference in the work of Aphra Behn". Aphra Bebn Studies. Ed. J. Todd. Cambridge: Cambridge University Press. 219-234.

Peterson, M. 2007. "The Animal Apparatus: From a Theory of Animal Acting to an Ethics of Animal Acts". The Drama Review 51 (1): 33-48.

Prieto-Pablos, J. A. 2005. "Audience Deception and Farce in John Lacy's Sir Hercules Buffoon". Atlantis 27 (1): 65-78.

Shadwell, Thomas. 1679. A True Widow. A Comedy. London: Benjamin Tooke.

Shell, A. 1996. "Popish Plots: The Feign'd Curtizans in context". Aphra Behn Studies. Ed. J. Todd. Cambridge: Cambridge University Press. 30-49.

Spencer, J. 1993. "“Deceit, Dissembling, all that's Woman.” Comic Plot and Female Action in The Feigned Courtesans". Rereading Aphra Behn. History, Theory, and Criticism. Ed. H. Hutner. Charlottesville: University Press of Virginia. 86101.

Tate, N. 1693. A Duke and no Duke. London: Henry Bonwicke.

Todd, J. 1996. The Secret Life of Aphra Bebn. London: Andre Deutsch.

Tomé Rosales, A. 2009. “Analysing the Grotesque in Aphra Behn's The Rover I and II". The Grove 16: 219-230.

Tomé Rosales, A. 2013. "How Much of the French is in This': Aphra Behn's Use of Humour in Sir Patient Fancy (1678)". Odisea 14: 153-166. 